Henry Ford could move more quickly because his much smaller market could afford comparatively higher prices. To begin with, there was no need to invest huge sums of money in machinery for mass production, and no need to worry about the refined development of the components of which his motor cars were assembled. The link between modern technology and the other aspects of modern industry of which Galbraith complains is very much the same. Efficient production at low cost means planning ahead and persuades industrial corporations to insulate themselves as far as possible from the forces of the market. None of this conflicts with what Galbraith has to say, and indeed he is the first to admit that modern industry is capable enough when only the production of goods is in question. He is, however, a little mischievous, to say the least of it, when he attributes the change which has come over industry to the influence of a seemingly animate entity called technology. Society could have less of technology and therefore less of its supposedly malevolent influence if society would settle for a smaller volume of production.

There must also be doubt about the value of Galbraith's concept of the Educational and Scientific Estate-not quite the same thing as Dr D. K. Price intended a year ago with the title of his book The Scientific Estate. For one thing, it implies a degree of homogeneity which may be unrealistic. Worse still, it implies what may be too sharp a distinction between those with a university education and those without. As with what may be called. Snow's hypothesis, any attempt like this to cut the community up into intellectually distinct pieces is likely to founder on the rocks of careful observation. But this, perhaps, may not be part of what Galbraith intended, in which case it is a pity that he has given his critics more openings than they deserve. And in the last resort, of course, Galbraith is right to pin his hope for the future-pale though it may be-in the possibility that academics and like-minded people may be able to engage so successfully in the rough and tumble of deciding what goals should be chosen for industry, government and society at large that the modern world will be a better place. To put it at its most trivial, Galbraith is right in saying that you cannot rely on the forces of the economic market to ensure that unsightly advertising hoardings will not proliferate. He is also right in thinking that the universities and similar places are best placed, by virtue of their independence, to provide the kind of influence that society would find healthy. His book will do good in this direction, for it will be widely read and it is bound to be provoking. It remains to be seen whether academics, as is their custom, will think their public duty has been done when they have read the book. It is also an open question whether the strong and sometimes over-clear lines in which Galbraith's picture has been painted will serve as a spur to persuade the Educational and Scientific Estate that it could easily win more creative influence than it has or whether, on the other hand, it will become another excuse for inactivity.

\section{NO OIL ON WATER}

Some details of the appalling destruction of sea birds caused by the wreck of the Torrey Canyon are reported on page 1123 of this issue in a survey of 1,223 dead birds collected on Cornish beaches during the months following the disaster. What stands out is that mortality was almost exclusively restricted to two species of offshore swimming birds-78 per cent of the sample was guillemots and 20 per cent razorbills. Other species appear to have escaped major killing. The same two species formed respectively 81 per cent and 17.5 per cent of the much larger sample of 7,849 birds taken to the Cornish cleaning stations. A summary provided by the Royal Society for the Prevention of Cruelty to Animals (see page 1119) draws attention to the very low survival rate of birds at cleaning stations. About 450 of the 7,849 had been rehabilitated on April 17, and many of these have since died. A similar fate befell most of the 2,000 birds taken to cleaning stations in France. In other words, a little over 10,000 birds are known to have died and, given all the difficulties of recovering oil-soaked bodies, it is likely that a total of anything between 30,000 and 100,000 birds were killed.

Luckily, the damage to the English sea bird populations is not likely to prove permanent. Even the breeding populations of the southern guillemot Uria aalge albionis, which has for the past fifty years suffered increasingly from oil pollution, are expected to recover. The populations of puffins, guillemots and razorbills on the coast of Brittany have, however, suffered very badly and may well fail to recover.

As the figures show, and as the RSPCA and the Royal Society for the Protection of Birds would be the first to admit, the magnitude of the Torrey Canyon disaster completely overwhelmed the facilities of the cleaning stations. When oiled birds are arriving in thousands, there is little hope for most of them. If an oiled bird is to be cleaned and successfully rehabilitated it must be given constant and individual attention and many ornithologists believe that in emergencies like the Torrey Canyon wreck, it is better to kill the birds than to prolong their suffering in vain attempts to clean them. But if attempts to save birds are to be made at all, there is an urgent need of many more cleaning centres, perhaps mobile ones, and much more research into the way of cleaning contaminated birds. Apparently some of the $f 60,000$ collected by the World Wildlife Fund, the RSPCA and the RSPB in their joint Seabird Fund appeal is earmarked for thisthe $£ 5,000$ which the British Government contributed is to pay for the work done last spring - but the amounts available are not sufficient for all the future work that is needed. The RSPCA alone spent $f 7,000$ on cleaning operations after the Torrey Canyon wreck.

The figures in these reports show just part of the suffering that can result from a massive pollution of the sea, and unfortunately the Torrey Canyon disaster. though by far the worst in British waters, is by no means an isolated incident. Last year, 1,700 tons of 
oil were accidentally pumped from the German tanker Seestern into the River Medway-an estimated 8,000 birds were among the victims-and earlier this year a Greek tanker left behind 250 tons of oil in Milford Haven. What is being done to prevent oil pollution in the future? The shipping world is slowly accepting that the sea must not remain its largest and cheapest dustbin. An indication of this is that the Japanese Government seems to be on the verge of formally joining the Convention for the Prevention of Oil Pollution of the Sea-which does not imply that Japanese ships are responsible for most oil pollution. The Convention, which is now supported by the govern. ments of all the major maritime powers except Japan and the USSR, designates zones throughout the world where the discharge of oil is forbidden. Of course, it has no legal powers; if a ship breaks the rules on the high seas and is caught--which is rare-it can be punished only by the country of registration. There is a tortuous legal procedure by which any member nation which spots a transgression anywhere in the world reports the evidence to the flag government which, if satisfied that the evidence is sufficient to provide a case against the ship according to its own law, should take immediate procecdings against it. If Japan, the fifth largest maritime nation, does in fact join, the Convention's moral authority, if nothing else, will be greatly strengthened.

But obviously the only effective way to stop voluntary pollution is to remove the financial incentives. This could be done by making fines imposed on ships caught discharging oil so severe that ships' masters would not dare to risk the penalties. For example, why should not the signatories to the convention agree to ban from their ports any ship known to have caused wide-scale pollution? A subcommittee of the Inter-Governmental Maritime Consultative Organization (IMCO) is to meet in London next week and will be considering, among other things, ways of increasing the penalties for oil pollution, but nobody seems to think it will go so far as to recommend such radical measures.

Deliberate pollution is much more likely to stop when the oil companies develop ways of recovering the oil previously discharged and saving themselves some money. In the past, oil tankers returning empty to the oil fields have washed their tanks at sea to save a few hours sailing time and have discharged the washingoil and seawater. A system known as 'load on top', which prevents some of this waste and pollution, has been developed by the oil companies. With 'load on top' the tanks are washed with hot sea water, and all the washings are collected into a tank to separate, when the lower aqueous phase can be discharged. The oil companies make great claims for this system and even conservationists agree that it represents a considerable improvement, but an IMCO study found that it is not entirely within the pollution limit that the convention sets. 'Load on top' is still only a compromise between the old discharge system and the use of really effective separation plants. None the less, if it really does save money and reduce pollution as well, we can be sure it will find widespread acceptance.

Even in the unlikely event of all deliberate pollution ceasing, the risk of accidental pollution is increasing as more and more oil is transported. There will always be the spectre of a one or two hundred thousand ton tanker being wrecked. After the Torrey Canyon disaster, the British Government called for a special session of IMCO, which met in May, and which began a series of urgent studies into sea lanes, speed limits, crew training, construction of tankers and procedures for mobilizing national and international efforts to deal with pollution. Despite the protestations of the oil companies to the contrary, these studies clearly imply that the standards of safety and navigation of tankers can be greatly improved. As Torrey Canyon showed, to save a few hours sailing time some masters seem prepared to cut safety margins.

IMCO has also set in motion research into ways of dispersing oil without destroying marine flora and fauna-one of the problems of the Torrey Canyon disaster was that no one knew the toxic effects of the detergents used. The results of the IMCO studies are to be presented in 1968 and, if nothing else, they should lead to sensible speed limits and better defined sea lanes. The problem, however, as with all other international agreements, will be one of enforcement. Tradition apart, it is difficult to understand why shipping should not be as closely regulated as aircraft. May not the concept of untrammelled freedom of the high seas outlive its usefulness?

Apart from trying to prevent accidents, IMCO is also tackling the more important job of devising procedures for accidents. Delays in burning the Torrey Canyon, wrecked outside territorial waters, and the subsequent events leading to the melodrama in Singapore, where her sister ship was arrested by the British Government and only released on $£ 3$ million security, revealed the complete lack of internationally accepted procedures for obtaining adequate compensation for people and governments which suffer directly from pollution and for allowing a government to destroy a potential pollution hazard. Groups in the various member nations of IMCO are investigating the legal responsibilities of shipowners and masters whose vessels, though wrecked on the high seas, damage the livelihoods of an adjacent country. It is essential that some sensible code of practice for third party insurance be devised (Nature, 214, 1; 1967). They are also studying the extent to which a state threatened by a wreck outside its territorial waters can protect itself even if that necessitates destroying the vessel and cargo and so affects the interests of shipowners, salvage companies, insurers and even flag governments. The maritime nations must reach some firm agreement on this quickly and accept the inevitable but probably small increase in insurance costs. It is inconceivable that when the next loaded tanker is wrecked, it should be allowed to spew out thousands of tons of oil while there are protracted legal discussions between the parties involved. 